\title{
THE LINK BETWEEN REPLACEMENT LABOUR AND ERUPTION OF VIOLENCE DURING INDUSTRIAL ACTION
}

\author{
Mlungisi Tenza \\ LLB LLM \\ Lecturer, Durban University of Technology
}

\section{SUMMARY}

The use of replacement workers during strikes has been a cause for concern in recent years. Since industrial action often becomes violent, the question that arises is whether the use of replacement labour can be one of the factors that contributes to the eruption of such violence. This article investigates whether there is a link between the use of replacement labour and the eruption of violence during a strike. In doing this, the author refers to certain instances where such use has resulted in friction between striking employees and replacement workers. Strikers believe that the use of such workers robs them of their weaponry of strike. The argument goes on to say that such use enables the employer to not commit faithfully to negotiations because he or she does not feel the economic harm that the employees want to inflict, as he or she is able to continue with production or delivery, while the former suffer from the "no work no pay" rule. The article argues that in the presence of the provision in the Labour Relations Act that permits employers to use such workers, the relations between employers and unions will remain unhealthy, if not tense. The article further argues that such use will have the effect of protracting negotiations and delay dispute settlements. As a result, it is suggested that the relevant clause be removed from the Labour Relations Act.

\section{$1 \quad$ INTRODUCTION}

South Africa has experienced a number of violent strikes in recent years. Thus far no successful attempts have been made, or measures put in place to curb or reduce strike related violence. In the mining and transport industries, for example, violence during strikes has claimed the lives of many people. This article investigates whether the use of replacement workers could be a factor that contributes to the eruption of violence during strikes. The article further discusses the conditions under which an employer can lawfully employ replacement labour. It argues that the use of replacement workers triggers violence during strikes and that the provision that sanctions such as the use of replacement workers should be removed from the Labour Relations Act (LRA). ${ }^{2}$ The article concludes with a warning to employers that

\footnotetext{
The term "scab" labour is generally used for replacement workers in a rather derogatory sense. In this article the term replacement labour is used throughout.

2 Act 66 of 1995.
} 
they, in the meantime, must refrain from employing replacement labour where the working relationship is fragile, as replacement workers could be exposed to the hostile conduct of strikers.

\section{BACKGROUND TO THE USE OF REPLACEMENT LABOUR}

The question of whether replacement labour should be allowed or not, was a key point of contention during the negotiations that led up to the enactment of the LRA. There were few issues on which the views of trade unions and South African employers were more divided. Whereas employers lobbied for the right to use replacement labour to maintain production, the unions held the opinion that the main purpose of a strike was to stop production, and that the use of replacement labour would be contrary to such an aim. ${ }^{3}$ The suspension of production is usually a temporary measure until the parties reach agreement on the issues that affect them. To allow employers to continue with production during a strike through the use of replacement labour was considered by trade unions as an indirect way of strengthening the economic position of employers, and robbing the strike much of its intended effect, that is, to inflict economic harm on the employer.

The purpose of a strike is to force an employer to take the demands of employees seriously by the withdrawal of the labour from employees. It is also believed that through withdrawal of labour the employer will reconsider its position by either agreeing to demands or accelerate the process of negotiation(s) with a view to finding a solution. Where the labour potential of employees is replaced by the employment of replacement workers, a strike will lose its potential to remedy a grievance, or to resolve a dispute between the parties. ${ }^{4}$ Once an employer has appointed replacement labour, the desire to reach agreement is removed, as the employer will be able to continue to operate as usual while the regular workforce is on strike.

\section{THE LRA AND THE USE OF REPLACEMENT WORKERS}

The LRA does not expressly sanction the use of replacement workers during a strike but prohibits the use of replacement labour in certain instances. It provides that:

"An employer may not take into employment any person -

(a) to continue or maintain production during a protected strike if the whole or a part of the employer's services has been designated a maintenance service; or

(b) for the purpose of performing the work of any employee who is locked out, unless the lock-out is in response to a strike."

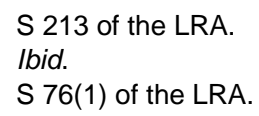


The LRA consequently allows the use of replacement labour in the case of all protected strikes, excluding only those by employees in maintenance services. This implies that an employer can use replacement labour in all unprotected strikes, even those by employees in maintenance services. The use of replacement labour is also permitted in defensive lockouts, but not in the case of offensive lockouts. ${ }^{6}$

\section{Protected strike}

If an employer is allowed to use replacement labour in all cases of protected strikes, with the exception of strikes where they are employed in a maintenance service, the question arises of what constitutes a strike, and secondly, when such strike will be protected. The LRA defines a strike as:

"The partial or complete concerted refusal to work, or the retardation of work, by persons who are or have been employed by the same employer or by different employers, for the purpose of remedying a grievance or resolving a dispute in respect of any matter of mutual interest between employer and employees, and every reference to 'work' in this definition includes overtime work, whether it is voluntary or compulsory."

Replacement labour can be used when employees stop work completely in order to compel the employer to agree to their demands or attempt to solve their grievances. As the use of replacement labour is only prohibited in the case of protected strikes by workers in a maintenance service workplace, it is necessary to establish when such a strike will be protected. Generally speaking, a strike, including one in a "maintenance service", is protected if it complies with sections 64 and 65 of the LRA. Section 64 prescribes the procedures that have to be followed to render a strike protected, unless the parties agreed to a different procedure in a collective agreement, in which case, the parties have to follow that agreed procedure.

Section 65 prohibits strikes in certain circumstances. These prohibitions are not aimed at denying workers the right to strike, but relate to agreements reached by unions with employers that workers will not resort to striking under certain circumstances. Examples of these are where there is agreement that the matter will be referred for arbitration, ${ }^{8}$ or where the agreement that regulates the issue is still in force.$^{9} \mathrm{~A}$ strike in a maintenance service will consequently have to comply with these two sections in order to enjoy protection, unless the employer and employees are party to a collective agreement that dictates a different procedure.

If a strike enjoys protection, participants enjoy immunity from civil actions. ${ }^{10}$ Such employees do not commit breach of contract by participating in a protected strike or any conduct in contemplation or furtherance of a protected strike. ${ }^{11}$ A protected strike results in a situation where employees

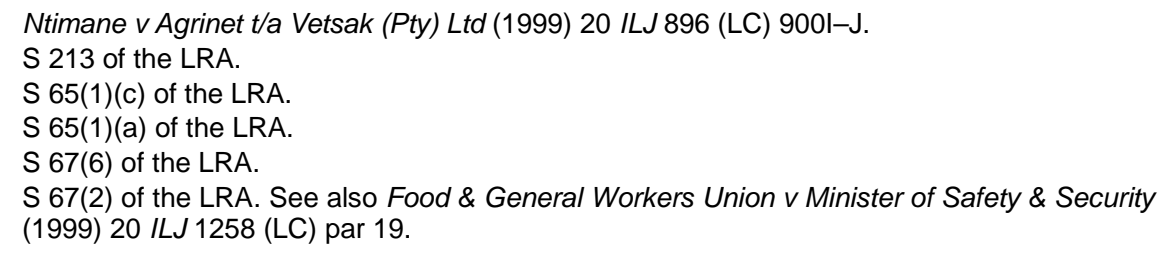


are temporarily relieved of their obligation to render service in terms of their contracts of employment, and the employer is temporarily relieved of its obligation to remunerate employees. ${ }^{12}$

Participants in a protected strike do not, however, enjoy absolute immunity as they could be dismissed for misconduct committed during the strike. ${ }^{13}$ They can also be dismissed due to operational requirements of the business, regardless of whether the economic condition of the business that results in such dismissal arises as a direct result of the strike. It is a fact that employers must do all they can do to prevent dismissal of employees. ${ }^{14}$ The use of replacement labour could be argued to be another way of avoiding loss to the business that could lead to dismissals. So, an employer who wants to dismiss employees for operational requirements will have to prove this if he or she had used replacement labour during a strike. If he or she fails to do so, this will mean that such use serves no purpose.

Section 76(1)(a) prohibits the employment of replacement labour in the case of a strike in a business of which the whole or a part has been designated as a maintenance service. This begs the question of what a maintenance service is. A maintenance service is defined in section 75(1) of the LRA a "service the interruption of which has the effect of material or physical destruction of any working area, plant or machinery". ${ }^{15} \mathrm{~A}$ service is designated a maintenance service if the employer successfully applied to the essential service committee to have the service declared a maintenance service. ${ }^{16}$ Du Plessis argues that the interruption of the removal of underground water in a mine shaft during a work stoppage may have the effect of flooding the workplace to the extent that mining the shaft may be impossible. ${ }^{17}$

The express exclusion of the use of replacement labour in the case of protected strikes in maintenance services seems superfluous, as employees in such services are prohibited from striking in terms of the LRA. ${ }^{18}$ The law provides particular procedures for the resolution of disputes for employees employed in maintenance services, including the referral of the matter for arbitration. ${ }^{19}$ In terms of section 75(5) the employer of a maintenance service can select certain employees to execute minimum services, in which case the other employees are not prohibited from striking. The article argues that section $75(5)$ needs to be given more strength and should take precedence over section 76(1)(a) to avoid friction between replacement labour and striking employees.

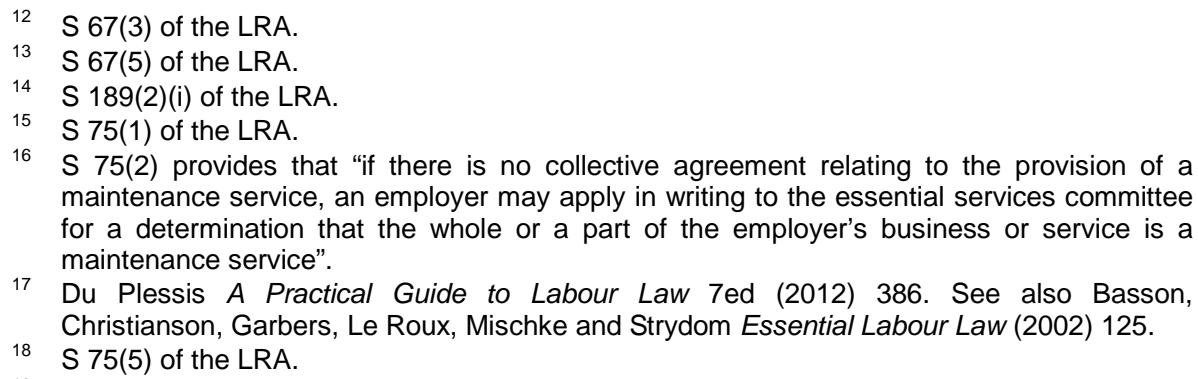

17 Du Plessis A Practical Guide to Labour Law 7ed (2012) 386. See also Basson, Christianson, Garbers, Le Roux, Mischke and Strydom Essential Labour Law (2002) 125.

18 S 75(5) of the LRA.

19 Ibid. 


\section{Use of replacement labour during a lockout}

In addition to the prohibition on the use of replacement labour discussed above, an employer may not hire replacement labour during an offensive lockout, that is, when the employer takes the initiative and locks out employees from the workplace in order to compel them to accept his or her demands. ${ }^{20}$ The power of a lockout is that the employer denies the lockedout employees the opportunity to earn their wages, ${ }^{21}$ thereby causing them financial harm. An employer's hope is that the harm inflicted on the employees will cause them to agree to his or her demands, rather than to lose more wages. ${ }^{22}$ In the case of a defensive lockout, the employer is not prohibited from using replacement labour, regardless of whether the strike is protected or not. ${ }^{23}$ In SACCAWU v Sun International, ${ }^{24}$ the union went on a protected strike for a limited number of days (21 September 2015 to 28 September 2015). The employer responded to the union's strike action by means of a lockout and subsequently, employed replacement workers in terms of section 76(1)(b) of the LRA. The question that the court had to answer was whether the employer may continue to use replacement labour after the strike has ended, that is, after 28 September 2015. It was held that the statutory right of an employer to hire replacement labour is restricted to the period to which a protected strike pertains, and not after it has ended. ${ }^{25}$

It is believed that the legislature limited the employment of replacement labour in the case of lockouts to defensive lockouts to encourage employers to use offensive lockouts only in exceptional circumstances, or where there are compelling reasons for them to resort to an offensive lockout, for example, in self-defence, where the union and its members have become aggressive. In my opinion the replacement labour clause in its current form seems to favour employers because, in most instances, employees initiate strikes to which employers respond and resort to defensive lockouts, in which case they are entitled to make use of replacement labour. Strikes are always used by employees as weapons against deadlocked negotiations, and the employer will promptly use this opportunity to hire replacement workers. In this regard employees commence the power play and the employer locks them out in order to protect his or her property. It is under these conditions that the employer is allowed to use replacement labour.

The use of replacement workers, regardless of whether the service is a maintenance service or not angers striking employees, and causes unnecessary conflict with striking employees, which will be avoided if employers act within the law. Strikers should also be advised to avoid getting angry so easily and take law in their own hands, but to let the negotiations process proceed without disturbance, as the use of replacement labour may be another method of dealing with the issues at hand, therefore to prevent

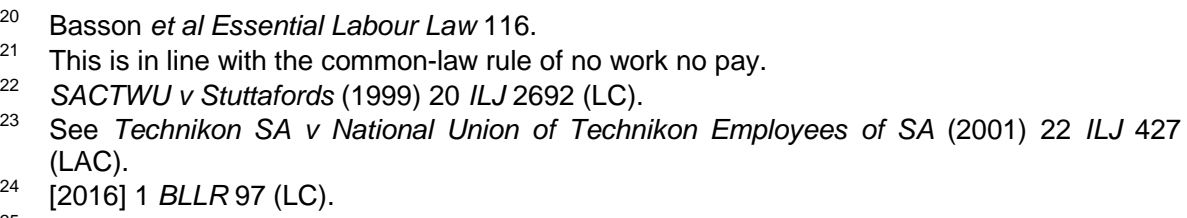


the total shut down of the business and loss of customers during the period where the employees are on strike. They should hold the employer accountable through the legal measures created. For example, by applying for an interdict to prevent the employer from using the replacement labour. An interdict is a court order which restrains a party to a contract from doing something that is forbidden by the contract or in conflict with contractual obligations. ${ }^{26}$

The employer is not only prohibited from using replacement labour under certain circumstances, but is also prohibited from making use of temporary employment services or an independent contractor. ${ }^{27}$ A temporary employment service is a person or business that procures or provides employees to perform work, or render services for a client and remunerate those employees. ${ }^{28}$ An independent contractor, on the other hand, refers to a person who offers work or service in terms of which the latter undertakes to build, manufacture, repair within a certain period, and in return the employer undertakes to pay the contractor a reward. Once the job has been finished the contract comes to an end. ${ }^{29}$

Section 76(2) prohibits the "taking into employment" of temporary employment services which implies a new employment relationship. This section does not seem to prohibit the use of employees who are already in the service of the employer in positions usually occupied by the strikers, to replace the labour ordinarily undertaken by the striking employees. ${ }^{30}$ Should non-striking workers refuse to perform the work of striking employees, their conduct would constitute insurbordination. ${ }^{31}$ Insurbordination occurs when an employee refuses to execute reasonable and lawful instruction from someone authorised to give him or her instructions in terms of the employee's conditions of service or employment. The employer is, however, prohibited from dismissing employees for refusing to do the work normally done by employees on strike, unless the work is necessary to prevent actual danger to life, personal safety or health, ${ }^{32}$ in which case the employer may lawfully dismiss the employees for refusing.

As already mentioned, the replacement labour clause does not explicitly authorise employers to use replacement labour, but prescribes instances where such labour is prohibited. The aim of the LRA in allowing employers to use replacement workers is clearly to allow a business to continue to operate, as a total shutdown of a business could have irreparable consequences for both the employer and the employees, with the latter

26 An Interdict is a court order which restrains a party to a contract from doing something that is forbidden by the contract or in conflict with contractual obligations, Thompson $v$ Voges 1988 (1) SA 691 (A) 711; Knox D'Arcy Ltd v Jamieson 1996 (4) SA 348 (A); and Atkin v Botes unreported (566/2010) [2011] ZASCA 12 (9 September 2011).

27 S 76(2) of the LRA.

28 Du Plessis A Practical Guide to Labour Law 43. See also Kelly Industrial Ltd v CCMA (2015) 36 ILJ 1877; and SA Transport \& Allied Workers Union obo Dube v Fidelity Supreme Cleaning Services Group (Pty) Ltd 1 Case No JS879/10 (LC).

29 Du Plessis A Practical Guide to Labour Law 10.

30 SACTWU v Coats SA (Pty) Ltd [2001] 8 BLLR 971 (LC).

31 See Du Plessis A Practical Guide to Labour Law 23.

$32 \mathrm{~S} 187(1)(\mathrm{b})$ of the LRA. 
losing their employment. ${ }^{33}$ The permanent closing of a business will not only affect the parties to the dispute, but the economy will also be affected, as the dismissed employees could add to the number of unemployed. ${ }^{34}$

The author opines that during negotiations every attempt should be made to avoid the potentially negative consequences of a strike. In order to prevent the total shutdown of a business and subsequent job losses, and as alternative to the use of replacement labour, the author suggests that, if negotiations fail, the parties should be compelled to resort to resolve their dispute through arbitration. Such arbitration should resort to interest arbitration which is applicable if the parties are unsuccessful in negotiating the terms of a collective agreement. ${ }^{35}$ South Africa does not have this remedy in its labour law, but it is suggested in this article that having this in law will have a positive effect on our violent industrial action in the Republic. Regarding interest arbitration the issues on which the parties have deadlocked are referred for resolution to a third party, an "interest arbitrator". This arbitrator will determine the manner in which the affairs of the parties will be dealt with in the future.

\section{THE EFFECTS ON THE EMPLOYER AND EMPLOYEES OF THE WITHDRAWAL OF LABOUR}

The withdrawal of labour affects the employer's business as there is no production or delivery of services except for the labour rendered by employees not on strike, such as those who are not unionised. At this point striking employees want to experience the effectiveness of their strike after having forced the employer to give in to their demands. The strike will, however, be ineffective if the employer is able to carry on with the business by making use of the services of replacement labourers, as he or she will then not suffer the harm the union wants to impose on it by the strike, if business operations can continue despite the strike.

The withdrawal of labour also affects the employees on strike, as they are not paid during a strike due to the application of the "no work no pay" rule. ${ }^{36}$ The LRA also maintains this common law rule by providing that "an employer is not obliged to remunerate an employee for services that the latter does not render during a strike or lock-out". ${ }^{37}$ Where an employee's remuneration includes payment in kind in the form of accommodation, food and other basic amenities of life, the employer has to continue providing this

33 Grogan Workplace Law 8ed (2005) 405.

34 Unemployment could lead to non-payment of basic services such as electricity and water. They might also be unable to maintain their bond and car payments, which could lead to repossession, just to mention few of the consequences that can flow from the loss of employment. Eventually, such people and their dependents may have to rely on the Government's already over-stretched social grant budget.

35 See Tenza "Consideration of Substantive Factors that Lead to Violent Strikes in South Africa: Some Lessons from Foreign Law and Possible Solutions" 2015 19(211) Law Democracy and Development 228.

36 Coin Security (Cape) v Vukani Guards \& Allied Workers Union (1989) 10 ILJ 239 (LC) $244 \mathrm{~J}-245 \mathrm{~A}$.

$37 \mathrm{~S} 67(3)$ of the LRA. 
if requested by the employee. ${ }^{38}$ The employer is expected to continue this kind of remuneration once so requested. At the end of the strike, the employer can recover the monetary value of such remuneration by way of civil proceedings in the Labour Court. ${ }^{39}$ Another way to recover this money from the employee is by subtracting this money from their salaries, provided they agreed to that procedure. ${ }^{40}$

Regarding the question of whether the employer has to continue providing benefits, such as medical aid, pension fund, and a housing subsidy to employees on strike, in SAMWU v City of Cape Town ${ }^{41}$ the Labour Court answered in the negative. It held that it was not an unfair labour practice for an employer to apply a policy of "no work, no pay, no benefits", because in principle, there was no difference between withholding a pro rata share of contributions in respect of benefits and withholding remuneration during a strike. This decision does not, however, set a clear precedent because section 5(1) of the LRA provides that no person may discriminate against an employee for exercising a right under the Act. This includes the right to strike. The withholding of benefits could be challenged on the ground that the employer's conduct is contrary to section 5(1) of the LRA, as it amounts to discrimination.

The withdrawal of labour could also have wider implications than those anticipated by the parties directly involved in the dispute. These could include economic stagnation at various levels of the economy and the loss of some of the employer's customers or clients who could transfer their loyalty to competitors of the employer, which would affect the business of the employer in the long run.

The article postulates that the use of replacement labour jeopardises the safety of replacement labourers, who come into contact with striking employees. Another concern is the effectiveness of the constitutional right of workers to strike, if the right can be infringed or rendered less effective by employers making use of replacement labour during the exercise of the right. These two issues are discussed more comprehensively in paragraphs 41 and 42 below.

\section{The relationship between replacement workers, striking employees and members of the public}

It is clear that the relationship between strikers and replacement workers is tense, not healthy, as violence most often occurs when they come into contact with one another during a strike. ${ }^{42}$ Violence, in the context of the crime of public violence, is defined as the unlawful and intentional commission, together with a number of people, of an act or acts which assume serious dimensions and which is intended forcibly to disturb the

\footnotetext{
38 Ibid.

$39 \mathrm{~S} 67(3)(\mathrm{b})$ of the LRA.

40 S 34(1) of the BCEA.

(2010) 31 ILJ 724 (LC).

42 Du Toit A Comprehenive Guide to Labour Law (2003) 315
} 
public peace and tranquility, or to invade the rights of others. ${ }^{43}$ In Security Services Employers' Organisation v SA Transport \& Allied Workers Union (SATAWU), ${ }^{4}$ a strike was called by the union after wage negotiations with the Security Employers' Organisation deadlocked. ${ }^{45}$ This strike was characterised by violence and intimidation. Many people were affected by the violent industrial action. The SABC reported that about 20 people were thrown off moving trains in Gauteng. Most of them were security guards who were employed during the strike and were believed to have been targeted by striking security guards. Two of the persons thrown off the trains were killed, while others were hospitalised in serious conditions. ${ }^{46}$

The court had an opportunity to decide on the liability for damage emanating from the conflict between strikers and replacement labour in Mahlangu $v$ SATAWU Passenger Rail Agency of $S A^{47}$ In this case the plaintiff was employed as a replacement worker in Springs, while the employer's domestic worker was on a strike called by her union. On her way to work one day, the plaintiff was approached by unknown persons who offered her full time employment in Johannesburg, to which they would accompany her. They boarded the train together at the Springs train station. During the train journey to Johannesburg the plaintiff was victimized, assaulted, stripped naked and thrown off the moving train near Springs. She suffered serious injuries. The unknown persons were later found to be members of SATAWU. She instituted action for damages against SATAWU, on the basis that the people who had victimised her were members of the union. It transpired during court proceedings that the employee whom she was replacing, was among the group of people who promised her full time employment and attacked her. The court held that SATAWU was not liable for the damage and the injury the plaintiff suffered. The reason the court advanced was that Springs was not within close proximity to Johannesburg, and that the union could not be held liable for conduct of members committed outside the premises where the march was held. ${ }^{48}$

Violent incidents will continue to occur until the replacement labour clause is removed from the LRA. The article recommends that, in the meantime, unions and employers should attempt to address any potential friction between replacement workers and strikers at the negotiating table before the strike commences, as it seems difficult, if not impossible, to deal with an issue once violence has broken out. The author opines that allowing employers to employ replacement labour during a strike puts the lives of replacement workers at risk. The author suggests that employers must be proactive and monitor the situation as it develops and take all reasonable and necessary steps to avoid responsibility for violence. One of the steps that employers could take is to discontinue making use of replacement labour, or using non-striking workers to execute the work of striking employees as soon as the situation becomes violent.

\footnotetext{
See Snyman Criminal Law 5ed (2008) 321.

(2006) 27 ILJ 1217 (LC).

The decision is not relevant to this discussion but only the facts.

25 May 2006 16h00 SABC news.

(2014) 35 ILJ 1193 (GSJ).

48 Par 91.
} 


\section{Is the impact of a strike diminished if replacement labour is used?}

It is an undeniable fact that South Africa is currently experiencing violent strikes. The Minister of Labour has said: "South Africa has been hit by an increase in strikes over the past four years with stoppages rising from 51 in 2009 to 114 in 2013 according to the Department of Labour's annual industrial action report." ${ }^{, 49}$ These strikes are not only violent but their long duration is also a concern, ${ }^{50}$ because during the process, employers use replacement workers.

There may be two reasons for the employers' desiring to use replacement labour during a strike. The first one is to avoid a total shutdown of the business and the loss of clients and customers. The use of replacement workers has the advantage of keeping the business alive during a strike. It is believed that the use of replacement labour is a compromise between granting the right to strike to employees, but nevertheless ensuring that businesses survive to avoid irreparable damage to both employers and employees. The second reason for the use of replacement labour is profit. It is believed that through the use of replacement labour employers make profit at the expense of striking employees because strikers believe that their employer is undermining their strike action, and will not feel the pressure they want to impose. ${ }^{51}$ This seems to be the root cause of friction between replacement workers and strikers. So, if employers use replacement labour just to make a profit that seems to provoke striking employees, and they seem to use every opportunity to fight against its utilization (practice). ${ }^{52}$

It is of common knowledge that, if an agreement has been entered into at a bargaining forum, such agreement applies to and binds the parties to the agreement and their members. ${ }^{53}$ Similarly, if the parties fail to reach agreement on the disputed issues at the bargaining forum, the union usually calls a strike, ${ }^{54}$ while the employer hopes that the "no work no pay"-rule will force the union to accept his or her offer. Therefore, the effect of using replacement workers in such cases has the potential to delay the settlement of disputes, that it increases hostility, and that it changes disputes about remuneration and working conditions, and focusses more on violence that has since erupted. It is also believed that its use angers and frustrates strikers, as they perceive it as an indication that the employer does not intend to bargain in good faith ${ }^{55}$ by involving third parties. Unions perceive

4917 August 2014 Business Times 5.

50 In 2014, a number of strikes took place. The longest strike in the South African history of industrial relations since the dawn of democracy in 1994 took place in the platinum industry. This strike lasted for four months, and was followed by a Post Office strike that lasted for almost two months, and the strike in the steel and engineering industries which lasted for almost four weeks.

6 June 2006 Mail \& Guardian 2.

52 See SATAWU v Garvas (2012) 33 ILJ 1593 (CC); and Mahlangu v SATAWU.

S 23(a) - (c) of the LRA.

54 See $s 64$ and 65 of the LRA.

55 Collective bargaining is a process whereby employers or employers' organisations bargain with employee representatives (trade unions) about terms and conditions of employment 
the use of replacement labour during a strike to defeat the purpose of the strike, which is to cause the employer economic harm, which is, in turn, part of the collective bargaining exercise. ${ }^{56}$ The exercise of economic pressure is the ingredient of collective labour relations if it rolls over to a strike. Therefore, when violence occurs, it seems that employers do not commit to the resolution of the issues between themselves and the trade union(s).

This article suggests that the issue of anger and frustration of striking workers should be looked at and addressed by the union leadership, as most of the decisions taken by strikers, such as fighting against the use of replacement labour, directly result from anger and frustration. It recommends that unions should adopt a uniform and principled approach when they deal with the issue of anger amongst striking workers. In doing so, unions might have to seek the services of experts, such as legal advisers, who could be contracted to advise strikers on the legality of each move they make; and psychologists who could, for example, counsel strikers on how to deal with the frustrations they experience. Labour disputes and finding solutions should be dealt with in a peaceful manner and in a peaceful environment, not clouded by violence and fear.

The bargaining system in South Africa is intended to promote economic democracy, that is, to enable workers to develop and administer their working conditions, and to provide the means to resolve conflicts amongst employers and employees peacefully. The author is of the opinion that the use of replacement workers violates the cardinal rule that collective bargaining should take place exclusively between the two clearly identified parties, the workers, represented by their union, and the employer. Allowing replacement labour undermines another cardinal rule of labour relations that there should not be any interference with the respective economic powers of the parties. While employers are permitted to make use of replacement workers to maintain, or continue operations during a strike, they should not be allowed to retain such workers in preference to striking workers after the strike has ended for the mere reason that they were engaged during a strike, as this will amount to automatic unfair dismissal. ${ }^{57}$

It is believed that the possibility of using replacement labour gives the employer an unfair advantage over striking workers, and that it eventually drags its heels during bargaining, saving on its remuneration budget and compromising the hope for a fair settlement with the strikers. The aim of the LRA is plainly to make a protected strike a simple endurance contest, that is, to determine whether the employer can do without the services of the strikers for longer than they can do without their wages. The use of replacement labour is contrary to this purpose. Such use has the potential of rendering the workers' right strike nugatory and changes collective bargaining to collective begging.

The ILO has also acknowledged this problem. Its Committee of on Freedom of Association has expressed its concern as follows:

and other matters of mutual interest, Van Niekerk, Chrstianson, Mcgregor, Smit and Van Eck Law@work 2ed (2012) 369.

$56 \quad$ Ntimane $v$ Agrinet t/a Vetsak par 13.

$57 \mathrm{~S} 187(1)(\mathrm{a})$ of the LRA. 


\begin{abstract}
"A special problem arises when legislation or practice allows enterprises to recruit workers to replace their own employees on a legal strike. The difficulty is even more serious if, under legislative provisions or case law, strikers do not, as of right, find their jobs waiting for them at the end of the dispute. The committee considered that this type of provision or practice seriously impairs the right to strike and affects the free exercise of trade union rights.
\end{abstract}

To avoid these consequences, the author argues that measures to reduce violence caused by the use of replacement labour should be seriously considered and that union leaders should ensure that they are in control of the movement of strikers. If the use of replacement labour is abolished, the immediate purpose of the strike, that is, to inflict economic harm on the employer, will be attained, as the employer will be left with none or few employees to continue production and will be able to produce only on a limited scale. The abolition of the use of replacement workers during a strike would increase the economic pressure on the employer which would pressurise him or her into considering to agree to the demands of the employees, or call for urgent negotiations to find a solution.

\title{
43 Striking a balance and legislative intervention
}

The issue of strikes and replacement labour will remain a problem for employers and employees, as long as employers want to make a profit and workers want their demands addressed as a matter of necessity. For example, if employers are not allowed to continue with production to avoid giving in to a strike, or are not allowed to follow other avenues to continue with production, or prevent the loss of profit such as by using replacement workers, it would amount to unfair encroachment on their autonomy and the way they run their businesses. On the other hand, allowing employers to take replacement workers into service to continue production during a strike weakens the effectiveness of strike action, leaving employees with little or no leverage. Our law has to strike a balance between the rights of employees to take industrial action in support of their claims for better conditions of work, and the rights of employers to operate their businesses without strikers resorting to violence.

Striking a balance between the two will not be an easy task and will require legislative intervention. As the use of replacement labour causes unrest, it should be revisited. The legislature will need to amend the LRA, particularly the section that regulates the use of replacement labour, to ensure that the interests of all parties are addressed. The legislature could consider scrapping replacement labour completely, because as it stands currently, it favours employers. If the clause that permits the use of replacement labour is retained, unions will have to educate their members about the advantages of the employer employing replacement workers during their strike. Unions should also play a positive role in informing their members about all the aspects of striking, and should also educate their members about tolerance with replacement workers. It should be made the

58 Gernigon, Odero and Guido I ILO Principles Concerning the Right to Strike (2000) 46-7. 
duty of the convening union to advise its members that the use of replacement labour should be interpreted as an attempt to find a healthy balance between the rights of employers and employees. This will ensure that workers retain the right to strike, but, on the other hand, avoid that the employer has to close down its operation, which would cause irreparable harm to the employees.

\section{THE EMPLOYMENT OF FOREIGN NATIONALS AS REPLACEMENT LABOUR}

There has been a growing concern that some employers try to sidestep labour laws by employing foreign nationals to do unskilled work in preference to local nationals for several reasons. ${ }^{59}$ Employers might take advantage of the illegal status of some foreign nationals and their fear of being deported to their home countries if reported to the Department of Home Affairs. Employers exploit the desperation for employment by these people, knowing that they will not be reported to the Department of Labour for their non-compliance with labour laws.

Some employers do employ foreign nationals while their employees are on strike. This has caused anger and worsened the hatred local nationals, and especially the unemployed, have towards them. There are two reasons for the hatred against the use of these nationals as replacement labour, and that they are ordinarily employed at the expense of local nationals. Strikers feel that without the work of foreign nationals, the employer would be more amenable to their demands, while the unemployed feel that they could have been employed as replacement labourers, had it not been for the availability of the foreign nationals.

It must be noted that it is not unlawful for anyone to employ a foreign national to work in the Republic, however, the employer has to comply with the applicable law. ${ }^{60}$ The law in the Republic requires that any person who employs a non-South African must comply with certain prescribed requirements. In terms of the Immigration Act a person who comes to South Africa in search of employment must have a passport and a work permit. ${ }^{61}$ The Act prohibits the employment of an illegal foreigner, unless the proper documentation that authorises him or her to work in the Republic, has been obtained from the relevant authorities. ${ }^{62}$ The employer must take reasonable steps to ensure that a foreign national that he or she intends to employ is in possession of such documents to avoid that the employment contract is illegal.

In short, an employer is not exempt from complying with the law regulating the entry of foreign nationals in the Republic, unless he or she can prove

\footnotetext{
59 S 1 of the Immigration Act 13 of 2011 defines a foreign national as a person who is not a citizen of the Republic of South Africa.

60 The applicable laws in this regard is the Immigration Act, the LRA, and the Basic Conditions of Employment Act, which prescribes the maximum hours of work an employee may work under normal circumstances and as overtime.

$61 \mathrm{~S} 11(2)$ of the Immigration Act.

$62 \mathrm{~S} 38(1)$ of the Immigration Act.
} 
that the employment of such national was made in good faith. ${ }^{63}$ An employer will, for example, be acting in good faith if the employee provided him or her with fraudulent documents that enabled him or her to enter the Republic and find employment, and the employer then employed the person on the strength of the documents in the belief that they were legitimate. If an employer employs a foreign national in violation of the Immigration Act, he or she is guilty of an offence punishable with imprisonment. ${ }^{64}$

A contract can also be void if its conclusion is contrary to a legislative provision. ${ }^{65}$ Consequently a contract with a foreign national who is in the country illegally is void $a b$ initio. In this regard, the contract will be unlawful because of non-compliance with legislation. Case law has held, however, that an employer who has concluded such a void contract with a foreign national is entitled to use the remedies provided by labour legislation, such as the LRA and other legislation applicable in employment contracts. ${ }^{66}$ For example, such employee is entitled to approach the CCMA if the employer has contravened one or more of his or her rights as employee.

In Discovery Health Ltd $v$ Commission for Conciliation Mediation and Arbitration, ${ }^{67}$ the employee had a temporary residence and work permit. His permit was not renewed in time and expired. When the company discovered that his permit was no longer valid, it dismissed him. He approached the CCMA for relief. The CCMA held that it had no jurisdiction to hear the matter because the contract was unlawful as he had failed to comply with the Immigration Act, which requires a valid work permit. This decision was, however, reversed in the Labour Appeal Court where it was held that an illegal foreigner is entitled to protection by the labour laws of the Republic and, that the CCMA did have jurisdiction to determine whether the employee was indeed an employee for the purpose of section 185 of the LRA, and consequently entitled to the remedies offered by South Africa's labour legislation. ${ }^{68}$ It can be concluded from this decision that a distinction can be made between the performance of work that is illegal and work that is illegally performed. ${ }^{69}$ The "performance of work that is illegal" means the person who performs the work does not comply with the applicable law. For example, an immigrant who does not have a valid passport. "Work that is illegally performed" refers to the situation where the person has complied with relevant laws, but is not permitted to do the job because certain conditions of authorisation have not been fulfilled, for example, someone with an expired work permit. If the work permit has expired it does not mean

\footnotetext{
$\mathrm{S} 38(3)$ (a) of the Immigration Act.

$S 49$ of the Immigration Act.

65 Absa Insurance Brokers (Pty) Ltd v Lutting 1997 (4) SA 229 (SCA); Pottie v Kotze 1954 (3) SA 719 (A); and Metro Western Cape (Pty) Ltd v Ross 1986 (3) SA 18 (A).

66 Discovery Health Ltd $v$ Commission for Conciliation Mediation and Arbitration (case No. JR2877/06 dated 28 March 06); Vundla and Millies Fashions (2003) ILJ 462 (CCMA); Georgieva-Deyanova v Craighall Spar (2004) 9 BALR 11143 (CCMA); and Moses v Safika (2001) 22 ILJ 1261 (CCMA).

67 Discovery Health Ltd $v$ Commission for Conciliation Mediation and Arbitration.

68 [2010] JOL 25578 (LAC).

69 Le Roux "When Does an Alien Become an Employee? Foreign Workers and their Rights
} under the LRA" 200817 Contemporary Labour Law 84. 
that the person is an illegal immigrant. Such a permit can be renewed and the person can continue working as normal. ${ }^{70}$

Foreign nationals are willing to accept poor working conditions and lower wages as a means of survival. This leads to attacks on them by nationals. The Daily News reported that a supermarket and wholesaler in Isipingo (Durban) was involved in a labour protest with workers. ${ }^{71}$ In the Isipingo area in Durban, employees went on strike after they had failed to reach agreement with their employer. During the strike the employer made use of the services of foreign nationals as replacement labour. Violence, directed at the foreign nationals doing the replacement labour, erupted. The violence was later directed at all foreign nationals in the area, and spread to other townships. Some foreign nationals lost their lives. The author advises employers to be careful not to risk the lives of these nationals by using their services during strikes, as this will cause grave problems when they employ foreign nationals. It is imperative that employers ensure that they act within the law. This will not only affect the people in his or her workplace but will also the larger society.

\section{CONCLUSION}

The use of replacement labour has contributed to a large extent to the frustration of striking employees with unresolved disputes, and their feeling that their bargaining power is diminished if the employers' production is able to continue. The financial pressure that a strike is intended to have on both parties, is less severe on an employer who can make use of replacement labour.

The author recommends that the provisions regarding replacement labour be amended to ensure that equal pressure in order to resolve a dispute is put on employers and employees during a strike. Alternatively, the provisions could be removed from the LRA all together, which will reduce the potential of friction between replacement labour and striking workers, and consequently reduce the possibility of violence occurring. Violence between replacement labour and will continue to erupt until the matter of replacement labour is addressed to the satisfaction of both employers and employees.

70 See Discovery Health Ltd $v$ Commission for Conciliation Mediation and Arbitration.

71 "Crisis Talks on Isipingo Violence" 1 April 2015 IOL http://www.iol.co.za/news/crimecourts/crisis-talks-on-isipingo-voilence-1840126 (accessed 2016-05-26). 